\title{
Haptoglobin Synthesis. I. In Vivo Studies of the Production of Haptoglobin, Fibrinogen, and $\gamma$-Globulin by the Canine Liver*
}

\author{
Chester A. Alper, $\dagger$ John H. Peters, $\ddagger$ Alan G. Birtch,§ and \\ Frank H. GardNER \| \\ (From the Richard C. Curtis Hematology Research Laboratory and the Department of \\ Surgery, Peter Bent Brigham Hospital, and the Departments of Medicine, \\ Bacteriology and Immunology, and Surgery, Harvard Medical School, \\ Boston, Mass.)
}

Haptoglobin is an $\alpha_{2}$ plasma glycoprotein that forms a stable complex with hemoglobin (1-5). The complex is cleared from the plasma much more rapidly than free haptoglobin so that marked hypo- or anhaptoglobinemia is a concomitant of hemolysis $(6,7)$. Since free hemoglobin passes readily into the urine, whereas the complex, perhaps owing to its much greater size, does not, haptoglobin may play a role in the conservation of iron by the body $(5,7)$. Haptoglobin concentration increases markedly in man $(8-12)$ and animals (13-15) in the presence of inflammation or tissue necrosis. Estrogen administration depresses the haptoglobin concentration in the serum of man (10).

The site of synthesis of this protein is unknown although the liver has been suggested (16), for it is known that in some instances of parenchymatous liver disease haptoglobin concentration is reduced $(10,17)$. At least theoretically this might be the result of decreased synthesis by a damaged organ. However, increased hemoglobin

* Supported by grants AM 00965, T1 AM 5241-06, A1 05691, and I-F2-AM-21,373-01 from the U. S. Public Health Service.

Reported partially in an abstract in Clin. Res. 1964, 12, 219.

† Trainee in hematology (T1 AM 5241-06), U. S. Public Health Service. Address requests for reprints to: Dr. Chester A. Alper, Peter Bent Brigham Hospital, 721 Huntington Avenue, Boston, Mass. 02115.

$\ddagger$ Advanced research fellow, American Heart Association.

$\S$ Postdoctoral research fellow, National Institutes of Health.

II Supported in part by U. S. Public Health Service Research Career Program Award (HE-K3-14927) from the National Heart Institute. turnover (18-23) and failure to metabolize estrogens (24) are common features of these cases and could produce the observed hypo- or anhaptoglobinemia. Therefore, this is inconclusive evidence for production of this protein by the liver (10). Possible direct evidence that haptoglobin is synthesized by the liver of the infected mouse was recently presented (25).

The present studies were designed primarily to test the hypothesis that haptoglobin is produced by the liver in the dog. If the hypothesis is correct, there should be no incorporation of administered $\mathrm{C}^{14}$-amino acid into this protein in the hepatectomized animal. Also, under suitable conditions, it should be possible to observe higher specific $\mathrm{C}^{14}$ radioactivity of haptoglobin isolated from blood leaving the liver than from that entering it in the intact $\operatorname{dog}$ after $\mathrm{C}^{14}$-amino acid is given. To obtain a better understanding of the kinetics of haptoglobin synthesis, it would also be helpful to compare the incorporation curves in plasma with those in lymph. Finally, a comparison of the haptoglobin incorporation curves with the incorporation of the labeled amino acid into fibrinogen, a protein known to be produced by the liver (26-32), and $\gamma$-globulin, known to be synthesized chiefly in sites outside the liver (31, 33-38), would provide useful confirmatory information.

\section{Methods}

Animals

Apparently healthy mongrel dogs weighing between 16.5 and $22 \mathrm{~kg}$ were used. They were maintained on the routine laboratory diet. Each animal received an injection of turpentine $(0.5 \mathrm{ml}$ per $\mathrm{kg})$ in multiple subcutaneous sites of the hindquarters while under pentobarbital anesthesia. 


\section{Operative procedures}

All procedures were performed under pentobarbital anesthesia with the animals placed on respirators ${ }^{1}$ adjusted to a tidal volume of $350 \mathrm{ml}$. About 65 hours after the turpentine injection, when haptoglobin synthesis is maximal (39), two sorts of operations were carried out. Two dogs (C and D) underwent hepatectomy with the establishment of polyethylene portal-jugular and inferior vena caval-jugular shunts and the placing of a catheter in the left common iliac vein. In four animals, the liver was left in situ, and catheters were inserted into the portal and hepatic veins (40) and thoracic duct (dogs F; G, I, and J). After completion of the preparation, all dogs received 250 to $300 \mu \mathrm{c}$ of glycine-2- $\mathrm{C}^{\mathbf{1 4}}$ intravenously over a 10 -second period. .

\section{Blood and lymph samples}

Blood was withdrawn simultaneously from each catheter into syringes containing 3\% EDTA in normal saline (1 vol EDTA: 10 vol blood). Collection of each 10 -ml sample required 15 to 20 seconds. Blood samples were taken at 10 minutes following isotope administration and then hourly from the two hepatectomized animals for a total of 3 hours and 40 minutes and 6 hours,

1 Harvard Apparatus Co., Dover, Mass. respectively. Blood samples from the other four dogs were collected at 5 - to 10 -minute intervals, beginning 10 to 20 minutes after isotope administration, for a total period of up to 1 hour. Lymph was collected continuously into tubes containing 0.5 to $1.0 \mathrm{ml} \mathrm{EDTA}$ for 5- to 15-minute periods. Lymph flow was about $0.4 \mathrm{ml}$ per minute.

\section{Protein fractionation}

Plasma was obtained from blood, and lymph was freed of cells by centrifugation.

A) Haptoglobin. Three $\mathrm{ml}$ of plasma or 1 to $2 \mathrm{ml}$ of lymph was diluted with an equal volume of $0.85 \%$ saline. Saturated ammonium sulfate solution ( $\mathrm{pH} \mathrm{7.0)}$ was added with mixing to a final saturation of $45 \%$. After standing for 2 hours at $4^{\circ} \mathrm{C}$, the samples were centrifuged at $105,400 \times g$ for 15 minutes, and the supernatant (45\% sup) and precipitate ( $45 \%$ ppt) were separated. Saturated ammonium sulfate solution was added to the $45 \%$ sup to a final saturation of $50 \%$, and the mixture was allowed to stand and was centrifuged as outlined above. The precipitate from this step (45 to $50 \%$ ppt) was dissolved in a small amount of water and dialyzed exhaustively against $0.85 \%$ saline. This material on vertical starch gel electrophoresis and staining with amido black $(41,42)$ with and without added hemoglobin is shown in Figure 1.

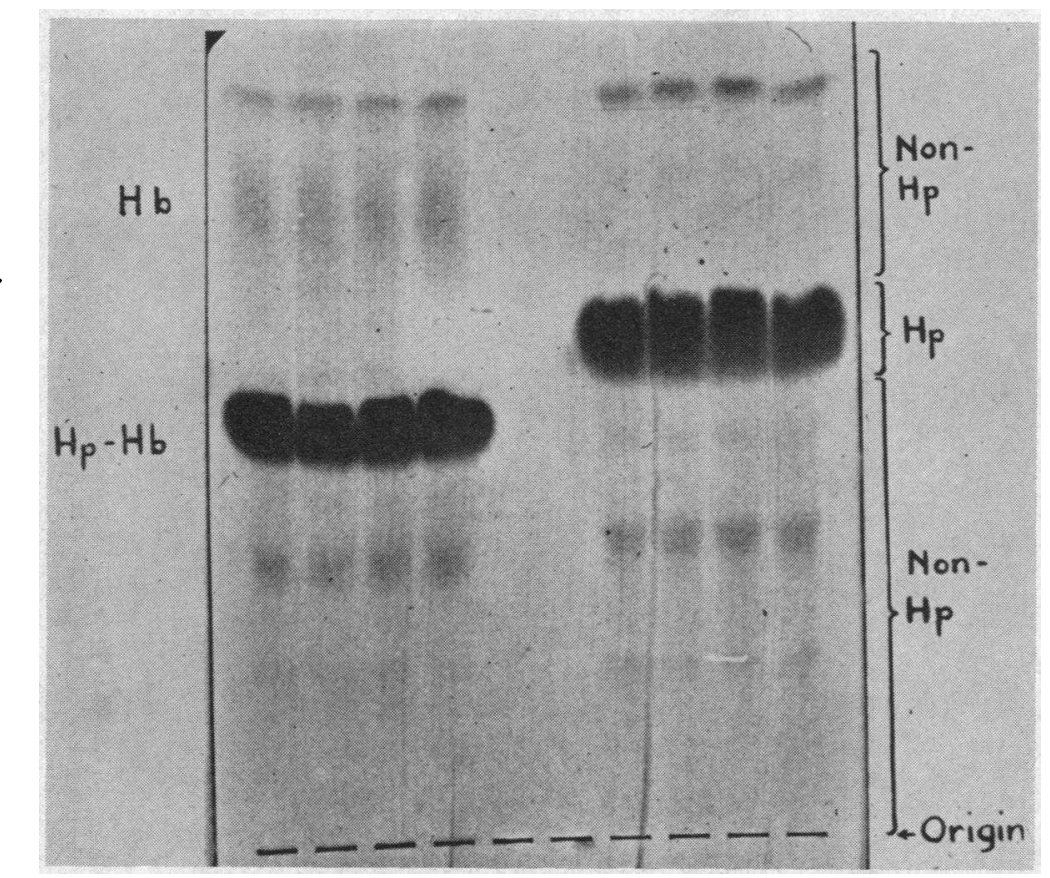

Fig. 1. Starch GEL ELECTROPHORETIC PATtERNS OF HAPtoglobin PREPARATIONS WITH AND WITHOUT ADDED HEMOGLOBIN. The four patterns to the left show preparations with added human hemoglobin $(\mathrm{Hb})$ in excess of the binding capacity of the haptoglobin. The patterns on the right are the same preparations without hemoglobin. The areas of the stained gels used for determining the percentage of $\mathrm{C}^{14}$ radioactivity in haptoglobins $(\mathrm{Hp})$ and nonhaptoglobin (non- $\mathrm{Hp}$ ) proteins are indicated at the extreme right. 
TABLE I

The percentage of $C^{14}$ radioactivity in haptoglobin in 16 preparations*

\begin{tabular}{cccc}
\hline \hline $\begin{array}{c}\text { Sample } \\
\text { no. }\end{array}$ & $\begin{array}{c}\text { \% of total } \\
\text { radioactivity in } \\
\text { haptoglobin† }\end{array}$ & $\begin{array}{c}\text { Sample } \\
\text { no. }\end{array}$ & $\begin{array}{c}\% \text { of total } \\
\text { radioactivity in } \\
\text { haptoglobin } \dagger\end{array}$ \\
\hline 1 & 88.8 & 9 & 90.9 \\
2 & 88.6 & 10 & 89.8 \\
3 & 89.6 & 11 & 91.5 \\
4 & 90.9 & 12 & 89.0 \\
5 & 92.4 & 13 & 93.7 \\
6 & 88.5 & 14 & 92.4 \\
7 & 89.4 & 15 & 92.0 \\
8 & 94.2 & 16 & 91.3 \\
\hline
\end{tabular}

* Obtained from hyperhaptoglobinemic dog plasma from animals who received glycine-2-C $C^{14}$ from 1 to 6 hours before sampling.

$\dagger$ See text for method of determining percentage of radioactivity in haptoglobin.

B) Gamma globulin. The $45 \% \mathrm{ppt}$ from the above fractionation was dissolved in a small amount of water and dialyzed exhaustively against $0.01 \mathrm{M}$ Tris-phosphate buffer $\mathrm{pH} 8.0$ or $0.005 \mathrm{M}$ phosphate buffer $\mathrm{pH} 6.4$ and passed through a column containing 200 to $600 \mathrm{mg}$ DEAE cellulose equilibrated with the same buffer. The columns were washed with this buffer, and the protein eluted was collected and concentrated by dialysis against a concentrated solution of polyethylene glycol $20 \mathrm{M}$ (Carbowax $)^{2}$ and then against $0.85 \%$ saline. This material on paper electrophoresis (43) contained only diffusively migrating $\gamma$-globulin, but on immunoelectrophoresis using rabbit anticanine plasma antiserum two or three minor non- $\gamma$ contaminants could be seen in some samples.

C) Fibrinogen. Approximately $10 \mathrm{NIH} \mathrm{U}$ of bovine thrombin was added with mixing to $1.0-\mathrm{ml}$ samples of the

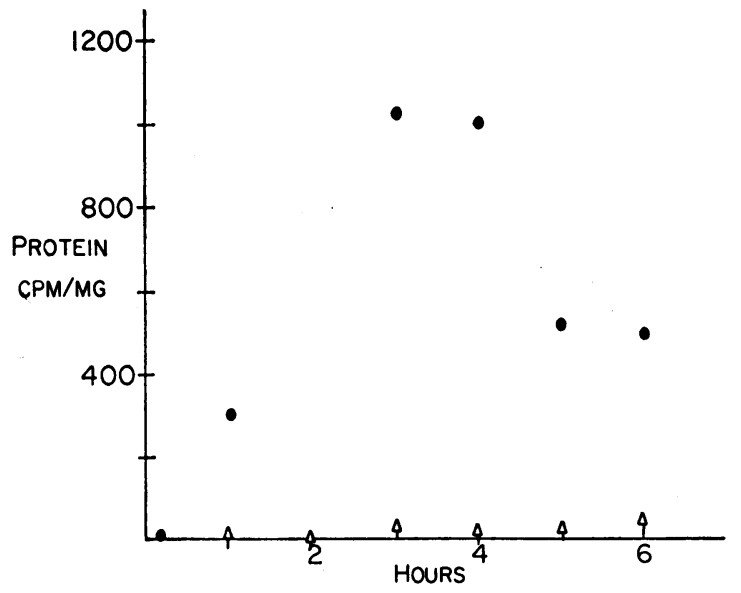

Fig. 2. InCORPoration OF GLYCINE-2-C ${ }^{14}$ INTO PLASMa HAPTOGLOBIN AND $\boldsymbol{\gamma}$-GLOBULIN IN THE HEPATECTOMIZED DOG (EXPERIMENT D). Closed circles (O) indicate $\boldsymbol{\gamma}$-globulin- $\mathrm{C}^{\mathbf{1 4}}$ specific activity, and open triangles $(\Delta)$ represent haptoglobin- $\mathrm{C}^{14}$ specific activity.

\footnotetext{
2 Union Carbide Chemical Co., New York, N. Y.
}

plasma and lymph samples or, in a few instances, to the dialyzed $45 \%$ ppt before extraction of $\gamma$-globulin. The samples were incubated at $37^{\circ} \mathrm{C}$ for 2 hours. The clots were wound on glass rods and then washed for 1-hour periods in two changes of $0.85 \%$ saline and two changes of deionized water. The washed clots were dried for 48 hours at $73^{\circ} \mathrm{C}$.

\section{Determination of specific activities}

Fifty- $\mu 1$ samples of purified haptoglobin and $\gamma$-globulin solution were added directly to the liquid scintillation counting system described by Nathan, Gabuzda, and Gardner (44). Dried clots were weighed, combusted, and counted as described by these authors for hemoglobin. The protein content of the haptoglobin and $\gamma$-globulin solutions was determined by the Folin-Ciocalteu method (45) standardized by micro-Kjeldahl analysis (46).

TABLE II

The incorporation of glycine-2-C $C^{14}$ radioactivity into plasma haptoglobin and $\gamma$-globulin in the hepatectomized dog

\begin{tabular}{cccc}
\hline \hline & $\begin{array}{c}\text { Hours } \\
\text { after } \\
\text { glycine- } \\
2 \text {-C14 } \\
\text { admin- } \\
\text { istered }\end{array}$ & $\begin{array}{c}\text { SA of } \\
\text { haptoglobin }\end{array}$ & $\begin{array}{c}\text { SA of } \\
\gamma \text {-globulin }\end{array}$ \\
\hline Exp. & & $c p m / m g$ & $c p m / m g$ \\
$\mathrm{C}$ & 0.17 & 1 & 75 \\
& 1.00 & 2 & 261 \\
& 2.00 & 9 & 118 \\
& 3.00 & 13 & 458 \\
& 3.67 & 11 & 104 \\
& 0.17 & 0 & 5 \\
& 1.00 & 10 & 307 \\
& 2.00 & 11 & 1,023 \\
& 3.00 & 22 & 1,004 \\
& 4.00 & 23 & 515 \\
& 5.00 & 23 & 512 \\
& 6.00 & 42 & \\
\hline
\end{tabular}

To demonstrate that the specific activity of the isolated haptoglobin was indeed that of this protein and not disproportionately influenced by some minor contaminant with high specific activity, the following analysis was made. Sixteen haptoglobin samples with high specific activity were subjected to vertical starch gel electrophoresis $(41,42)$ and stained with amido black. Since no visible bands with the original mobility of haptoglobin appeared after hemoglobin was added (Figure 1), the haptoglobin spot was regarded as containing pure haptoglobin. This spot (Hp-gel) and the gel containing nonhaptoglobin protein behind and in front of it (non-Hp-gel) were cut from the stained gel as indicated in Figure 1, dried at $80^{\circ} \mathrm{C}$ for 48 hours, weighed, and ground to a fine powder with a mortar and pestle. A portion of gel outside the zone of protein migration (blank-gel) was treated similarly. Weighed samples of approximately $50 \mathrm{mg}$ of dried $\mathrm{Hp}$-gel, non-Hp-gel, and blank-gel were combusted and counted as described for fibrinogen. 
Blank-gel counts per minute served as background. The mean percentage of radioactivity attributable to haptoglobin in the 16 samples was $90.8 \pm 1.8 \%$ ( $1 \mathrm{SD}$ ). The actual values are given in Table $\mathrm{I}$.

\section{Results}

As Figure 2 illustrates, there is no incorporation of radioactivity into haptoglobin isolated from the plasma of a hepatectomized dog in experiment $D$. The excellent incorporation of radioactivity into $\gamma$-globulin from the plasma of this same animal is also seen in this Figure. The results of experiment $\mathrm{C}$ are similar and are presented in Table II.

Figure 3 shows the incorporation of radioactivity into plasma haptoglobin isolated from simultaneous hepatic and portal vein samples over a 1 -hour period in experiment $F$. The haptoglobin

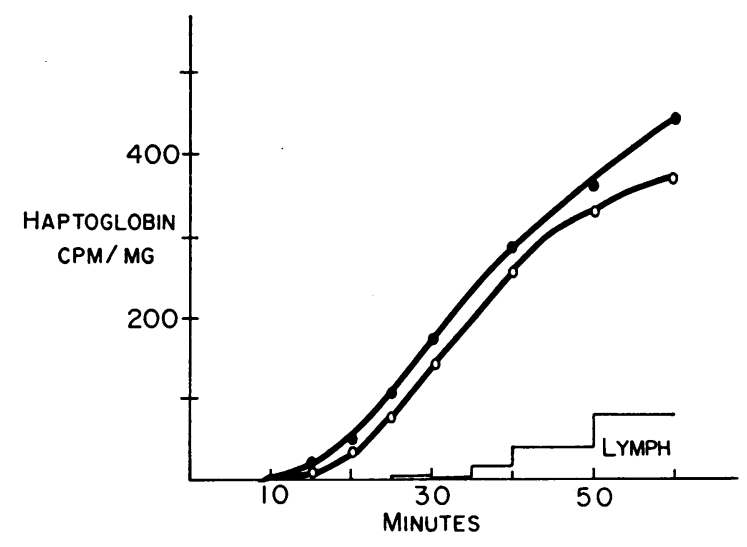

Fig. 3. INCORPORATION OF GLYCINE-2-C ${ }^{14}$ INTO HAPTOGLOBIN ISOLATED FROM HEPATIC VEIN PLASMA (O), PORTAL VEIN PLASMA (O), AND THORACIC DUCT LYMPH (BLOCKS) IN EXPERIMENT F. Lymph flow was fairly constant at about $0.4 \mathrm{ml}$ per minute, and all lymph was collected for extraction of protein.

TABLE III

The incorporation of glycine-2-C ${ }^{14}$ radioactivity into haptoglobin, fibrinogen, and $\gamma$-globulin isolated from portal and hepatic vein plasma and thoracic duct lymph*

\begin{tabular}{|c|c|c|c|c|c|c|c|c|c|c|}
\hline \multirow[b]{2}{*}{ Exp. } & \multirow{2}{*}{$\begin{array}{l}\text { Minutes after } \\
\text { glycine-2-C14 } \\
\text { administered } \dagger\end{array}$} & \multicolumn{3}{|c|}{ SA of haptoglobin } & \multicolumn{3}{|c|}{ SA of fibrinogen } & \multicolumn{3}{|c|}{ SA of $\gamma$-globulin } \\
\hline & & PV & $\mathrm{HV}$ & $\overline{T D}$ & PV & $\mathrm{HV}$ & TD & $\overline{\mathrm{PV}}$ & $\mathrm{HV}$ & TD \\
\hline & & \multicolumn{3}{|c|}{$c p m / m g$} & \multicolumn{3}{|c|}{$c p m / m g$} & \multicolumn{3}{|c|}{$c p m / m g$} \\
\hline $\mathrm{F}$ & $\begin{array}{l}15(0-15) \\
20(15-20) \\
25(20-25) \\
30(25-30) \\
35(30-35) \\
40(35-40) \\
50(40-50) \\
60(50-60)\end{array}$ & $\begin{array}{r}10 \\
32 \\
76 \\
145 \\
139 \\
258 \\
332 \\
369\end{array}$ & $\begin{array}{r}18 \\
48 \\
103 \\
172 \\
185 \\
287 \\
361 \\
447\end{array}$ & $\begin{array}{r}0 \\
0 \\
0 \\
3 \\
1 \\
14 \\
37 \\
79\end{array}$ & $\begin{array}{r}3 \\
29 \\
85 \\
145 \\
233 \\
281 \\
390 \\
460\end{array}$ & $\begin{array}{r}7 \\
42 \\
139 \\
183 \\
258 \\
305 \\
414 \\
495\end{array}$ & $\begin{array}{r}0 \\
3 \\
1 \\
2 \\
3 \\
8 \\
42 \\
192\end{array}$ & $\begin{array}{r}5 \\
16 \\
36 \\
63 \\
115 \\
127 \\
137 \\
203\end{array}$ & $\begin{array}{r}4 \\
18 \\
38 \\
82 \\
83 \\
119 \\
152 \\
208\end{array}$ & $\begin{array}{r}0 \\
7 \\
119 \\
39 \\
131 \\
89 \\
272 \\
226\end{array}$ \\
\hline G & $\begin{array}{l}15(0-15) \\
20(15-20) \\
25(20-25) \\
30(25-30) \\
45(30-45)\end{array}$ & $\begin{array}{r}24 \\
64 \\
131 \\
261\end{array}$ & $\begin{array}{r}2 \\
30 \\
83 \\
146 \\
279\end{array}$ & $\begin{array}{r}0 \\
2 \\
0 \\
5 \\
47\end{array}$ & $\begin{array}{r}47 \\
214\end{array}$ & $\begin{array}{r}19 \\
69 \\
134 \\
280\end{array}$ & 18 & $\begin{array}{r}30 \\
50 \\
78 \\
160\end{array}$ & $\begin{array}{r}7 \\
28 \\
42 \\
82 \\
148\end{array}$ & $\begin{array}{r}7 \\
25 \\
60 \\
59 \\
151\end{array}$ \\
\hline I & $\begin{array}{l}20(0-20) \\
25(20-25) \\
30(25-30) \\
35(30-35) \\
40(35-40) \\
45(40-50) \\
52(50-60) \\
60\end{array}$ & $\begin{array}{r}57 \\
110 \\
168 \\
266 \\
316 \\
402 \\
473 \\
557\end{array}$ & $\begin{array}{r}83 \\
138 \\
219 \\
296 \\
351 \\
409 \\
537 \\
579\end{array}$ & $\begin{array}{r}2 \\
2 \\
3 \\
7 \\
13 \\
56 \\
150\end{array}$ & $\begin{array}{r}64 \\
\\
292 \\
441 \\
537 \\
697 \\
630 \\
742\end{array}$ & $\begin{array}{l}124 \\
258 \\
\\
532 \\
558 \\
\\
838 \\
939\end{array}$ & $\begin{array}{r}6 \\
1 \\
2 \\
2 \\
8 \\
45 \\
182\end{array}$ & $\begin{array}{r}15 \\
35 \\
23 \\
\\
61 \\
100 \\
95\end{array}$ & $\begin{array}{l}19 \\
20 \\
63 \\
33 \\
35 \\
97 \\
88 \\
70\end{array}$ & $\begin{array}{r}6 \\
10 \\
8 \\
13 \\
43 \\
101 \\
127\end{array}$ \\
\hline $\mathrm{J}$ & $\begin{array}{l}20(0-20) \\
25(20-25) \\
30(25-30) \\
35(30-35) \\
10(35-40) \\
45(40-50) \\
50(50-60) \\
60\end{array}$ & $\begin{array}{l}172 \\
317 \\
501 \\
658 \\
694 \\
731 \\
811 \\
995\end{array}$ & $\begin{array}{r}226 \\
383 \\
543 \\
725 \\
749 \\
805 \\
903 \\
1,073\end{array}$ & $\begin{array}{r}1 \\
0 \\
7 \\
19 \\
39 \\
230 \\
407\end{array}$ & $\begin{array}{r}152 \\
304 \\
485 \\
718 \\
878 \\
931 \\
1,101 \\
1,325\end{array}$ & $\begin{array}{r}191 \\
403 \\
601 \\
844 \\
939 \\
1,070 \\
1,333 \\
1,557\end{array}$ & $\begin{array}{r}0 \\
2 \\
1 \\
39 \\
214 \\
823 \\
1,373\end{array}$ & $\begin{array}{r}91 \\
169 \\
209 \\
361 \\
116 \\
508 \\
751 \\
740\end{array}$ & $\begin{array}{r}81 \\
121 \\
230 \\
528 \\
336 \\
220 \\
1,247 \\
918\end{array}$ & 96 \\
\hline
\end{tabular}

* $\mathrm{PV}=$ obtained from portal vein plasma, $\mathrm{HV}=$ obtained from hepatic vein plasma, and $\mathrm{TD}=$ obtained from thoracic duct lymph.

$\dagger$ The numbers to the left outside parentheses refer to time of plasma sampling; those within parentheses indicate the period over which lymph was collected. 
specific activity is higher in hepatic vein plasma than portal vein plasma for all points. The results of experiments G, I, and J (Table III) similarly show all hepatic vein haptoglobin specific activities higher than the corresponding portal vein values. Furthermore, haptoglobin isolated from thoracic duct lymph has much lower specific activity at any given time and begins to rise significantly only after some 35 minutes.

Although the absolute specific activities are not comparable, the incorporation curves for fibrinogen in experiment I, shown in Figure 4, are quite similar to those of haptoglobin. They show the same difference in specific activity of fibrinogen isolated from hepatic and portal plasma and the same slow and delayed rise in lymph specific activity. Experiments $F, G$, and $\mathrm{H}$ resulted in curves similar to experiment I (Table III).

By contrast, $\gamma$-globulin specific activities in this same experiment (Figure 5) show no consistent difference between the veins (although the experimental variation in points is greater), and the appearance of radioactivity in the lymph is prompt and of about the same magnitude as that in the plasma. The $\gamma$-globulin and fibrinogen curves for experiments F, G, and J (Table III) are essentially the same as in experiment $I$.

\section{Discussion}

The failure of the hepatectomized dog to synthesize haptoglobin as well as the finding that

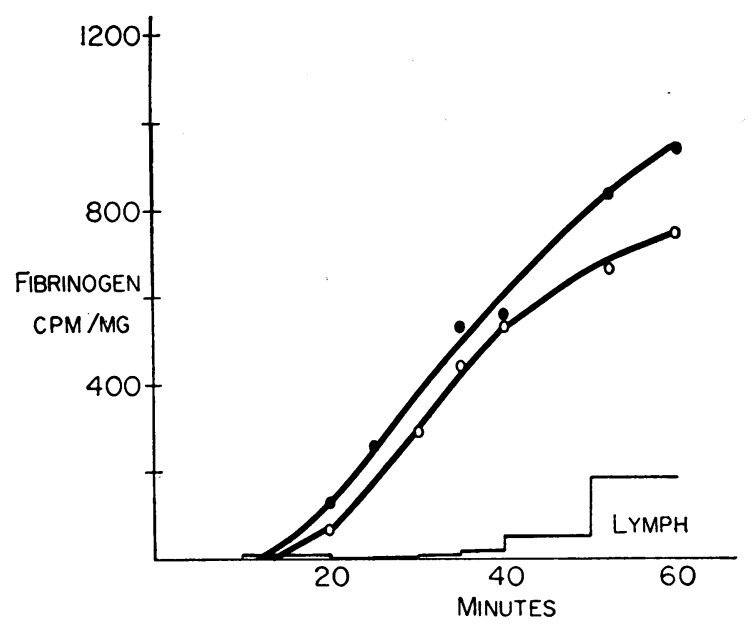

Fig. 4. INCORPORATION OF GLYCINE-2-C ${ }^{14}$ INTO FIBRINOGEN ISOLATED FROM HEPATIC VEIN PLASMA ( ), PORTAL VEIN PLASMA (O), AND THORACIC DUCT LYMPH (BLOCKS) IN EXPERIMENT I.

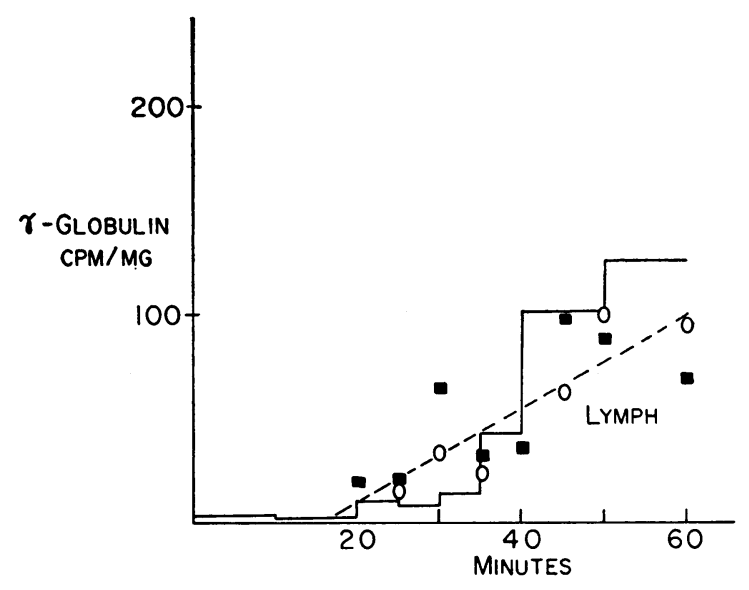

Fig. 5. INCORPORATION OF GLYCINE-2-C ${ }^{14}$ INTO $\gamma$-GLOBULIN ISOLATED FROM HEPATIC VEIN PLASMA ( $\square$ ), PORTAL VEIN PLASMA (O), AND THORACIC DUCT LYMPH (BLOCKS) IN EXPERIMENT I.

haptoglobin specific activity is higher in hepatic vein than portal vein plasma indicates that in the dog this protein is produced by the liver. These data do not exclude other sites of synthesis but make them unlikely. Since selective catabolism of nonradioactive haptoglobin molecules would appear to be very improbable, the inflowoutflow difference in specific activities across the liver most probably represents incorporation of radioactive amino acid into newly synthesized protein in this organ. This reasoning was the basis of the classical work of Miller, Bly, and Bale $(36,37)$ concerning the site of synthesis of the plasma proteins in the rat. They found little incorporation of radioactive amino acid into $\alpha$ globulins in the hepatectomized animal, whereas incorporation into $\alpha$-globulins was excellent in their isolated, perfused rat liver preparation. Kukral and associates (31) obtained somewhat different results; they found that approximately one-third the normal amount of labeled amino acid was incorporated into $\alpha$-globulins by the hepatectomized dog. Whatever these $\alpha$-globulins are, these experiments indicate that haptoglobin is not one of them. These authors also observed, as we have, excellent incorporation of radioactivity into $\gamma$-globulin by the hepatectomized animal.

Williams, Asofsky, and Thorbecke (25) studied the incorporation of radioactive amino acid into plasma proteins by in vitro incubation of organ slices from infected mice. By using radioimmunoelectrophoresis they were able to show up- 
take of radioactivity into haptoglobin-hemoglobin complexes in incubation media from liver and possibly also spleen preparations but not from other tissues. The interpretation of these data is made difficult because mouse spleen is hematopoietic (47) and mouse blood has a rather high reticulocyte level (48), so that radioactivity may have been incorporated into hemoglobin and hence into hemoglobin-haptoglobin complexes, if hemoglobin from hemolysis of newly formed erythrocytes were released into the medium.

In all the present studies, haptoglobin behaved like fibrinogen, our model for a protein produced in the liver. Since both haptoglobin and fibrinogen appeared in the lymph well after the liver to thoracic duct transit time (about 8 to $14 \mathrm{~min}$ utes $)^{3}$ and specific activities rose only slowly, it would appear that release of protein from the site of synthesis in the liver is directly into the blood rather than into the lymph and thence to the blood. The prompt appearance and rapid rise of $\gamma$-globulin specific activity in the lymph speaks for the release of at least part of the newly synthesized protein directly into the lymph from sites outside the liver, as one might expect from the observations of Asofsky and Thorbecke (49).

It has been suggested that the rise in haptoglobin concentration in the serum following inflammation might be due to release of the protein from a preformed pool (11). Evidence refuting this hypothesis has also been presented (15). The present data suggest that the rise in serum haptoglobin level following inflammation is the result of increased synthesis with prompt appearance of newly synthesized molecules in the circulation.

\section{Summary}

The incorporation of glycine-2- $\mathrm{C}^{14}$ into plasma haptoglobin, fibrinogen, and $\gamma$-globulin is studied in two hepatectomized and four intact dogs during response to inflammation. There is incorporation of radioactivity into $\gamma$-globulin but not into haptoglobin in the hepatectomized animals. The specific activity of haptoglobin isolated from hepatic vein plasma is higher than that isolated

\footnotetext{
3 The liver to thoracic duct transit time was determined in these experiments by injecting a solution of Evans blue dye into the substance of the liver and noting the time of its first appearance in the lymph.
}

from simultaneously obtained portal vein plasma at all times up to 1 hour in the four intact dogs. This difference in specific activity is also observed in the case of fibrinogen. There is no difference in specific activity between $\gamma$-globulin isolated from portal vein plasma and that obtained simultaneously from hepatic vein plasma. Labeled haptoglobin and fibrinogen appear in thoracic duct lymph only after approximately 35 minutes, and specific activities are considerably lower than corresponding specific activities in the plasma throughout the period of study. In contrast, labeled $\gamma$-globulin appears in the lymph within 10 minutes, and specific activities are comparable to those in the plasma. These results provide evidence that haptoglobin is synthesized by the canine liver. They also indicate that newly synthesized haptoglobin and fibrinogen molecules enter the plasma directly, whereas $\gamma$-globulin is at least partially released directly into the lymph.

\section{Addendum}

A report (50) appeared after the preparation of this manuscript that describes observations of serum haptoglobin types in a case of human liver transplantation. The donor had type 2-2 haptoglobin, whereas the recipient's was type $2-1$. On the second day post-transplantation, the recipient had type $2-2$ haptoglobin in her serum, but no haptoglobin was demonstrable after this time. The patient received $7,000 \mathrm{ml}$ of blood during and after liver transplantation. The authors present these observations as evidence for production of haptoglobin by the human liver.

We have observed a similar situation in which a liver from a donor with haptoglobin type 2-1 was transplanted into a recipient with type $2-2$ haptoglobin. The recipient was transfused with $16,000 \mathrm{ml}$ of blood. Haptoglobin was demonstrable from the time of transplantation to death 11 days postoperatively, and at all times the haptoglobin was of mixed types, reflecting the mixture of types in the transfused blood.

\section{Acknowledgments}

We wish to express our appreciation for the technical assistance of Miss Domenica Paci, Miss Lynn Mirtl, and Mr. Paul Vernaglia. We wish also to thank Drs. A. H. Coons, C.-B. Laurell, and D. G. Nathan for helpful advice and criticism.

\section{References}

1. Polonovski, M., and M.-F. Jayle. Sur la préparation d'une nouvelle fraction des protéines plasmatiques, l'haptoglobine. C. R. Acad. Sci. (Paris) 1940, 211, 517. 
2. Van Royen, A. A. Haptoglobin. A Contribution to the Study of the $\alpha$-Globulins. Delft, Holland, Drukkerij Waltman, 1950, pp. 23-60.

3. Laurell, C.-B. Purification and properties of different haptoglobins. Clin. chim. Acta 1959, 4, 79.

4. Rowe, D. S., and J. F. Soothill. Observations on globin, hæmoglobin and haptoglobin using a rabbit antiglobin serum. Nature (Lond.) 1960, 186, 975.

5. Noyes, W. D., and C.-B. Laurell. The in vitro stability of the haptoglobin-hemoglobin complex. Scand. J. clin. Lab. Invest. 1961, 13, 625.

6. Laurell, C.-B., and M. Nyman. Studies on the serum haptoglobin level in hemoglobinemia and its influence on renal excretion of hemoglobin. Blood 1957, 12, 493.

7. Allison, A. C., and W. ap Rees. The binding of haemoglobin by plasma proteins (haptoglobins): its bearing on the "renal threshold" for haemoglobin and the aetiology of haemoglobinuria. Brit. med. J. 1957, 2, 1137.

8. Jayle, M.-F., and J. Badin. Signification et intérêt chimique de la formule protéique du plasma sanguin. Presse méd. 1953, 61, 343.

9. Jayle, M.-F., and G. Boussier. Les sérumucoïdes du sang, leurs relations avec mucoprotéines de la substance fondamentale du tissu conjonctif. Expos. ann. Biochim. méd. 1955, 17, 157.

10. Nyman, M. Serum haptoglobin. Scand. J. clin. Lab. Invest. 1959, 11 (suppl. 39), 87.

11. Murray, R. K., and G. E. Connell. Elevation of serum haptoglobin in rabbits in response to experimental inflammation. Nature (Lond.) 1960, 186, 86.

12. Schumacher, G. Über Haptoglobin und Nicht-Haptoglobin-Anteile der $\alpha_{2}$-Globuline bei entzündlichen Prozessen und bei Schwangerschaft. Geburtsh. u. Frauenheilk. 1962, 22, 1006.

13. Aronsen, K. F. Liver function studies during and after complete extrahepatic biliary obstruction in the dog. Acta chir. scand. 1961 (suppl. 275), 54, 76.

14. Laurell, C.-B., and C. Grönvall. Haptoglobins. Advanc. clin. Chem. 1962, 5, 135.

15. Miale, J. B., and J. W. Kent. Serum haptoglobin in rabbits after subcutaneous injection of Freund's adjuvant or turpentine. Proc. Soc. exp. Biol. (N. Y.) 1962, 111, 589.

16. Jayle, M.-F., and J. Moretti. Haptoglobin: biochemical, genetic and physiopathologic aspects. Progr. Hemat. 1962, 3, 342.

17. Jayle, M.-F., and J. Vallin. Variations de la formule protéique du plasma au cours des affections hépatiques. Sem. Hôp. Paris 1952, 28, 3133.

18. Eppinger, $H$. Die hepato-lienalen Erkrankungen in Enzyklopädie der klinischen Medizin, L. Langstein, C. von Norden, C. Pirquet, and A. Schittenhelm, Eds. Berlin, Springer, 1920, pp. 435-453.
19. Hyman, G. A., and H. Southworth. Hemolytic anemia associated with liver disease. Amer. J. med. Sci. 1951, 221, 448.

20. Chaplin, H., Jr., and P. L. Mollison. Red cell lifespan in nephritis and in hepatic cirrhosis. Clin. Sci. 1953, 12, 351.

21. Jandl, J. H. The anemia of liver disease: observations on its mechanism. J. clin. Invest. 1955, 34, 390.

22. Jones, P. N., I. M. Weinstein, R. H. Ettinger, and R. B. Capps. Decreased red cell survival associated with liver disease. Use of radioactive sodium chromate in measurement of red cell survival. Arch. intern. Med. 1955, 95, 93.

23. Zieve, L. Jaundice, hyperlipemia and hemolytic anemia: a heretofore unrecognized syndrome associated with alcoholic fatty liver and cirrhosis. Ann. intern. Med. 1958, 48, 471.

24. Cameron, C. B. The liver and steroid hormone metabolism. Brit. med. Bull. 1957, 13, 119.

25. Williams, C. A., Jr., R. Asofsky, and G. J. Thorbecke. Plasma protein formation in vitro by tissues from mice infected with staphylococci. J. exp. Med. 1963, 118, 315.

26. Doyon, M., and N. Kareff. Effet de l'ablation du foie sur la coagulabilité du sang. C. R. Soc. Biol. (Paris) 1904, 56, 612.

27. Nolf, P. Des modifications de la coagulation du sang chez le chien après extirpation du foie. Arch. int. Physiol. 1905, 3, 1.

28. Meek, W. J. Relation of the liver to the fibrinogen content of the blood. Amer. J. Physiol. 1912, 30, 161.

29. Whipple, G. H. Fibrinogen. I. An investigation concerning its origin and destruction in the body. Amer. J. Physiol. 1914, 33, 50.

30. Drury, D. R., and P. D. McMaster. The liver as a source of fibrinogen. J. exp. Med. 1929, 50, 569.

31. Kukral, J. C., J. D. Kerth, R. J. Pancner, D. W. Cromer, and G. C. Henegar. Plasma protein synthesis in the normal dog and after total hepatectomy. Surg. Gynec. Obstet. 1961, 113, 360.

32. Hamashima, Y., J. G. Harter, and A. H. Coons. The localization of albumin and fibrinogen in human liver cells. J. Cell Biol. 1964, 20, 271.

33. Bing, J., and P. Plum. Serum proteins in leucopenia. Acta med. scand. 1937, 92, 415.

34. Bjфrneboe, M., and $H$. Gormsen. Untersuchungen über das Vorkommen von Plasmazellen bei experimenteller Hyperglobulinämie bei Kaninchen. Klin. Wschr. 1941, 20, 314.

35. Fagraeus, A. Antibody production relation to the development of plasma cells. In vivo and in vitro experiments. Acta med. scand. 1948, 130 (suppl. 204).

36. Miller, L. L., and W. F. Bale. Synthesis of all plasma protein fractions except gamma globulins by the liver. The use of zone electrophoresis and lysine- $\epsilon-C^{14}$ to define the plasma proteins synthe- 
sized by the isolated perfused liver. J. exp. Med. 1954, 99, 125.

37. Miller, L. L., C. G. Bly, and W. F. Bale. Plasma and tissue proteins produced by non-hepatic rat organs as studied with lysine- $\epsilon-C^{14}$. Gamma globulins the chief plasma protein fraction produced by nonhepatic tissue. J. exp. Med. 1954, 99, 133.

38. Coons, A. H., E. H. Leduc, and J. M. Connolly. Studies on antibody production. I. A method for the histochemical demonstration of specific antibody and its application to the hyperimmune rabbit. J. exp. Med. 1955, 102, 49.

39. Alper, C. A., and J. H. Peters. Unpublished observations.

40. Shoemaker, W. C., W. F. Walker, T. B. Van Itallie, and F. D. Moore. A method for simultaneous catheterization of major hepatic vessels in a chronic canine preparation. Amer. J. Physiol. 1959, 196, 311.

41. Smithies, O. An improved procedure for starch-gel electrophoresis: further variations in the serum proteins of normal individuals. Biochem. J. 1959, $71,585$.

42. Poulik, M. D. Starch gel electrophoresis in a discontinuous system of buffers. Nature (Lond.) 1957, 180, 1477.

43. Laurell, C.-B., S. Laurell, and N. Skoog. Buffer composition in paper electrophoresis. Considerations on its influence, with special reference to the interaction between small ions and proteins. Clin. Chem. 1956, 2, 99.

44. Nathan, D. G., T. G. Gabuzda, and F. H. Gardner. Liquid scintillation counting of $\mathrm{C}^{14}$-labeled hemoglobin and hemin by a modified Schöniger technique. J. Lab. clin. Med. 1963, 62, 511.

45. Lowry, O. H., N. J. Rosebrough, A. L. Farr, and R. J. Randall. Protein measurement with the Folin phenol reagent. J. biol. Chem. 1951, 193, 265.

46. Kabat, E. A., and M. M. Mayer. Experimental Immunochemistry, 2nd ed. Springfield, Ill., Charles C Thomas, 1961, p. 480.

47. Jordan, H. E. Comparative hematology in Handbook of Hematology, 1st ed., H. Downey, Ed. New York, Hoeber, 1938, vol. 2, p. 810.

48. Isaacs, $R$. The effect of arsenic on the maturation of red blood cells. Folia haemat. (Lpz.) 1928, 37, 389.

49. Asofsky, R., and G. J. Thorbecke. Site of formation of immune globulins and of a component of $C^{\prime} 3$. II. Production of immunoelectrophoretically identified serum proteins by human and monkey tissues in vitro. J. exp. Med. 1961, 114, 471.

50. Merrill, D. A., C. H. Kirkpatrick, W. E. C. Wilson, and C. M. Riley. Change in serum haptoglobin type following human liver transplantation. Proc. Soc. exp. Biol. (N. Y.) 1964, 116, 748. 